futile, it is positively mischievous, for it raises an ideal which for the ordinary man is quite inappropriate during his preparation for a life of serious practical endeavour." The remarkable development of chemical industry in Germany has resulted much more from the large command of chemists and engineers of sound professional training and ability than from the possession also of an even larger supply of research chemists of mediocre ability.

Sir William Lever's paper is a weighty contribution to what is at the present crisis a very serious problem. One of the most distressing features of the times is the widespread unrest in the labour world concerning the division of the profits arising from the remarkable activity of certain industries connected with the war. So far it has not extended to any marked extent to the chemical industries, probably because these are not subjected to the same disturbing influences as, say, the coal-miners. But Sir William Lever's paper is a timely account, judicious, impartial, and dispassionate, of the working of a system which is pursued with signal advantage and success in the great organisation which he controls, and as such it may be commended to the thoughtful consideration of all employers of labour.

\section{THE ROYAL GEOGRAPHICAL SOCIETY'S WORK ON THE ONE-MILLION MAP.}

MR. A. R. HINKS, secretary of the Royal Weographical Society, described at a recent meeting of the society the work which has been carried out, and is still in progress, on a map on the scale $r / r, 000,000$. It is well known that, before the outbreak of war, conferences of representatives of the principal Powers had met in London and Paris, and had come to an agreement as to the production of a map on this scale, to cover ultimately all lands, on a uniform projection and with uniform methods of representation, etc. A few sheets had been produced in various countries. They were scattered, in some instances imperfect and not available in any quantity, and in any event useless to meet even partially the necessity which was felt, almost at the outset of the war, of a map to cover uniformly Western and Central Europe and Asia Minor and adjacent areas affected by military operations. Even for Europe no such map existed, and it was necessary, in taking a broad view of the operations, or for any such purpose as that which will ultimately become of prime importance, the tracing of boundaries, to pass at certain points from maps of a particular scale and method to others totally different in every respect. People are prone to comment that the scale $I / I, 000,000$ (nearly $\mathrm{I} 6$ miles $=\mathrm{I}$ inch) is too small even for such general purposes, but it is not so. It allows the representation of important places, railways, roads and boundaries, rivers, and elevation by means of contour lines, either alcne or in conjunction with layer colours.

$$
\text { NO. } 2387 \text {, voL. 95] }
$$

Such a map, then, was undertaken by the Royal Geographical Society under the direction of the Geographical Section of the General Staff. The society's responsibility has extended to the compilation of construction drawings from the materials available on the spot, while the engraving and reproduction is being carried out by the Ordnance Survey Department. Methods have been used which, if slightly rough, have allowed of high speed, and a number of the sheets are already on the market in a preliminary issue. The work at the society's house has been done by $\mathrm{Mr}$. Hinks and a number of volunteer fellows, all more or less accustomed to map-compilation, with the assistance of certain external advisers and a few trained draughtsmen.

Despite the possibilities for error which are inseparable from work done thus rapidly and without access to local information at the moment - possibilities which were frankly discussed by Mr. Hinks-there can be no question that a valuable and important task has been accomplished. Much experience has been gained. In certain respects the methods laid down at the international conferences have been improved upon. Two of the most important departments in which the work marks a real scientific advance are (I) the solid endeavours which have been made to overcome the immense difficulties of regularising the spelling of place-names in Central and Near Eastern Europe; (2) the contouring of the maps, which, in the same localities, of ten represents a reasoned collation of very imperfect sources, and the application to the data thus obtained of what may be called topographical sentiment of a high order. The systems of transliteration and hints as to pronunciation are indicated, where necessary, on the maps themselves. The work of compiling the physical outlines and contours has enabled a proper value to be set on many of the wellknown official and other maps; notably it has resulted in the detailed criticism of the great Austrian staff map of $1 / 75^{\circ}, 000$, which does not emerge triumphantly from this test.

It is to be hoped that on the solid foundation of preliminary work thus laid will be raised, after present exigencies have been met, a structure of permanent value to geography generally; these maps should ultimately be revised and executed by the best methods, excellent as the present results are for the time being.

\section{RECENT STUDIES IN THE DYNAMICS OF LIVING MATTER.}

THERE is no falling off in the stream of work which comes from Prof. Jacques Loeb's laboratory in the Rockefeller Institute, from which we have now before us some ten or a dozen papers, mostly by Prof. Loeb himself, all published since the beginning of last year. They deal with various subjects in that field of comparative physiology, or dynamical biology, which Loeb has so diligently reaped as well as sown. Most of them are concerned with one or other of three topics, the phenomenon of heliotropism, the in- 
exhaustible problem of growth, and, lastly, the conditions which determine or which prevent the entrance of the spermatozoon into the egg.

In Prof. Loeb's book, which bears the title set at the head of this short article; there is a wellknown chapter on heliotropism, that is to say on the tendency of plants to turn towards the light, and on other kindred phenomena manifested both in plants and animals; for the polypes of a hydroid colony such as Eudendrium, or the tube-dwelling worms such as Serpula or Spirographis, also bend towards the light, and if they be illuminated by a single beam they grow steadily in the direction of its rays. It is characteristic of the plant (or rather of the green plant) that it represents a peculiar type of machine twhich is capable of turning radiant energy into chemical energy, and so ultimately into mechanical work; and in the case of the plant, "the permanency of this kind of machine is guaranteed by the presence of an automatic arrangement, whereby their stems turn towards the light." So Loeb is inclined to read into this phenomenon what we might call a modified teleology, such indeed as, in one form or another, refuses to be kept out even of our most modern biological speculations.

In the chapter already alluded to, published some nine years ago, our knowledge was said to be very scanty as to the relative heliotropic efficiency of the various parts of the spectrum, little more being known than that the more refractive rays, the green, the blue, and the violet, were more effective than the yellow and the red. "There exists thus, apparently," said Prof. Loeb, "a division of labour, the longer light-waves accelerating assimilation, and the shorter waves accelerating heliotropism;"-just (we might say) as there is obviously a "division of labour" between the rays which illuminate and those which warm us.

Two of Prof. Loeb's recent papers (by Dr. H. Wasteneys and himself) (Pr. Nat. Acad. of Science, January, 1915, and Science, February 26 , 19I5) are devoted to the question of the identity of heliotropism in plants and animals, and thereby to an inquiry into the particular wave-lengths of light to which, in one case or another, they are most sensitive. Instead of exposing the organisms to the solar spectrum itself, as had been done in earlier and simpler experiments, the writers (using a carbon arc spectrum) allowed the light from particular portions of it to pass through narrow slits, and then reflected it in a monochromatic beam upon the subject of their experiments. They soon arrived at the simple but very remarkable result that there are two particular regions of the spectrum the rays of which are especially effective in causing organisms to turn, or to congregate, towards them; these regions lie (I) in the blue, in the neighbourhood of a wave-length of $477 \mu \mu$, and $(2)$ in the yellowish-green, in the region of $\lambda=534 \mu \mu$; and these two wave-lengths affect different organisms, with no very evident relation to the nature of these latter. Thus the blue rays (of $477 \mu \mu$ ) attract the infusorian Euglena, the No. 2387 , vou. 957 hydroid Eudendrium, and the seedlings of oats; while the yellowish-green rays (of $534 \mu \mu$ ) in turn affect the protozoon Chlamydomonas, the little water-flea Daphnia, and the larvæ of barnacles.

These facts add a quality of precision to many older and vaguer observations, for instance, to Paul Bert's discovery (in 1869) that Daphnia swims towards the light in all parts of the visible spectrum, but most rapidly in the yellow or the green. The particular wave-length of $534 \mu \mu$ is especially remarkable, because it coincides with a determination by Trendelenberg that the visual purple of the rabbit's eye (which is not affected by red and very little by yellow light) is bleached most rapidly by light the wave-length of which is $53^{6} \mu \mu$. It would seem, according to Loeb, that among the lower organisms we have to deal with two separate photosensitive substances, which determine their heliotropic reactions; that the se are distributed without regard to the systematie boundaries, even between plants and animals; and that one of the two, occurring even among very lowly organisms, has characters similar to, and is perhaps identical with, the visual purple of the highest type of eye.

In another paper (Science, November 6, I914), still dealing with the effects of light, Prof. Loeb relates some remarkable observations on the action of ultra-violet rays upon unfertilised eggs, adding by these new experiments a curious detail to the many facts regarding artificial fertilisation, by chemical or physical means, which we associate with his name as their prime discoverer. On the ground that ultra-violet rays are known to have a sterilising effect, that is to say to be capable agents in the destruction of cell-life, and that, according to Loeb's own experiments, the very substances which induce "cytolysis" in the living cell are also capable (under proper conditions) of producing artificial parthenogenesis, Loeb thought it likely that these rays would also prove to be effective stimuli, under the appropriate conditions, of parthenogenetic development. He exposed the unfertilised eggs of a sea-urchin for ten minutes to.the light of a quartz mercury arc lamp, ana found that the majority of the eggs formed "fertilisation membranes"; when kept cool they turther proceeded to segment, but ere long perished; an addition of hypertonic sea-water, however, enabled them to develop into larvæ, though few advanced beyond the gastrula stage. It was remarkable that a cover-glass, o. $1 \mathrm{~mm}$. thick, was sufficient to prevent all action on the part of the light, a fact which bears closely on the wave-length of the rays which produced the action.

The discovery here mentioned is certainly interesting as a specific case of the effect of radiant energy on 1iving protoplasm; but its precise degree of interest turns largely on the importance which we may attach to the formation of a surface-membrane as an essential preliminary to the development of the egg. According to Loeb this phenomenon is of supreme importance; for the question why an unfertilised egg cannot grow, and why a fertilised egg can grow and divide, depends, according to 
him, entirely on the condition of the surface layer of the egg; the nature of this cortical layer determines whether the egg be in an active or a passive phase, and the essential factor is a change in the rate of oxidation, to which the condition of the cortical layer directly leads. "The forces which induce the egg to develop are, therefore, localised at the surface of the cell." This is a somewhat hard saying, but in Prof. Loeb's hands it leads to many suggestive and stimulating reflections. The whole subject is discussed in his book on "Artificial Parthenogenesis, etc." (19I3), and in a paper now before us, on the Stimulation of Growth (Science, May 14, 1915).

\section{D'Arcy W. ThOMPson.}

\section{SIR SANDFORD FLEMING.}

\section{$\mathrm{T}^{\mathrm{H}}$}

death of Sir Sandford Fleming on July 22nd at eighty-eight years of age has deprived the world not only of one of its greatest engineers, whose constructive works revolutionised trade and commerce by providing increased facilities for intercouse, but also of one who in various ways proved himself a pioneer, advocating and supporting measures the importance of which had not yet penetrated the public mind. He will be longest remembered for his work on the Canadian Pacific Railway and for his successful advocacy of a cable across the Pacific, which has proved of so much value to the commercial world. But in smaller matters he exerted himself not less strenuously and usefully. In a new country where material interests are many and pressing, he early saw the necessity of upholding pure science for the encouragement it could give to arts and industry, and with this view, so far back as 1849, he promoted the foundation of the Canadian Institute, which after demonstrating its usefulness in various directions, was recently incorporated under a Royal Charter.

Not less farseeing and useful was Sir Sandford Fleming's proposal in 1879 to legalise a universal day, beginning at mean noon of Greenwich time, the hours being counted continuously from $0 \mathrm{~h}$. to $24 \mathrm{~h}$. Five years later this suggestion bore fruit at the conference at Washington, summoned to consider more uniform methods of reckoning time, and at which it was resolved to adopt a single prime meridian for all nations in place of the initial meridians, favoured as this mode of reckoning was by international jealousies. At this conference Sir Sandford Fleming represented Canada, and it was there that the zone system of reckoning with which his name has been intimately connected was first ventilated. The convenience of adopting a standard time differing by an exact number of hours from universal time was insisted upon, and it was shown that it was not necessary, as maintained at a previous conference at Rome, to retain exact local time side by side with universal time. We have not yet achieved the arduous task of counting the hours consecutively from 0 to $24 \mathrm{~h}$. as recommended, but the methud is so eminently desirable in civil affairs as being thoroughly explicit and rendering unnecessary the distinguishing suffix a.m. or p.m., that we may hope the practical advantages will become apparent to the public as they were to the eminent engineer whose death we regretfully record.

\section{NOTES.}

THE Société Helvétique des Sciences Naturelles will

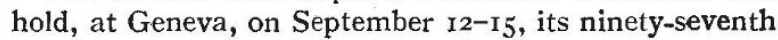
annual session, which will coincide with the hundredth anniversary of its foundation. On account of the disturbed conditions existing at the present time, the council of the society bas decided to celebrate this anniversary very quietly, and not to send the usual invitations to foreign scientific societies, or to men of science residing outside Switzerland.

THE Toronto correspondent of the Times announces that the Commission appointed by the Ontario Government to investigate the production and shipment of nickel in relation to the conditions created by the war consists of Mr. G. T. Holloway, of London (chairman); Prof. W. G. Miller, provincial geologist; Mr. McGregor Young, K.C., Toronto; and Mr. T. W. Gibson, Deputy-Minister of Mines. It is understood that in the course of its investigation the Commission will visit England and Norway and the New Caledonia mines in the South Seas. The Commission will also consider if nickel can be successfully refined in Canada. The importance of nickel as a munition metal was described by Prof. Carpenter in an article in Nature of July 15 (p. 539).

A Notable instance of the advantage to the State of calling in the aid of science in relation to difficult problems bearing directly on the well-being of our fighting forces is illustrated in the exhibit recently installed in the central hall of the Natural History Museum showing the work done in connection with an investigation undertaken jointly by the War Office and the Museum to determine the origin of damage to army biscuit by insect pests, and to prevent or minimise such infestation. Attention was directed to the matter some time ago by the fact that ration biscuits exported to the colonies became after a time quite unfit for consumption, owing to the ravages of certain moths and beetles-this was specially noted in South Africa, Ceylon, Gibraltar, Malta, Mauritius, and the Sudan. In answer to an application from the War Office, the trustees of the British Museum placed at the disposal of the military authorities for the purpose of the inquiry the services of Mr. J. Hartley Durrant, the expert in charge of the collection of microlepidoptera at South Kensington. It is most satisfactory to learn that these researches, which have been carried out jointly by the two departments concerned, extending over a period of three years, have ensured the protection of army biscuit from the possibility of such attacks by insects in the future. The insects met with during the inquiry were all widely distributed species the range of which has doubtless been greatly extended by commerce.

$$
\text { No. } 2387 \text {, VOL. } 95]
$$

